\title{
THE EFFECT OF DIFFERENT QUALITY PELLETED FEEDS ON THE GROWTH OF GREEN CATFISH (Hemibagrus nemurus) IN FLOATING NET CAGE
}

\author{
Ningrum Suhenda")\#, Reza Samsudin"), Estu Nugroho*), and Anang Hari Kristanto**) \\ *) Research Institute for Freshwater Aquaculture \\ *) Central Research Institute for Fisheries Aquaculture
}

(Received 13 July 2010; Accepted 6 December 2010)

\begin{abstract}
The study was conducted to evaluate the different protein content of fish feed on the growth performance of green catfish (Hemibagrus nemurus). Two thousand fingerlings averaging $3.92 \pm 0.32 \mathrm{~g}$ of individual body weight were stocked in each floating net cage $(3 \mathrm{~m} \times 3 \mathrm{~m} \times 3 \mathrm{~m})$ in Musi River, South Sumatra. They were fed daily for four months with feed protein content of $27 \%$ and $31 \%$. The feed was given in pelleted form at $4 \%-8 \%$ of the total body weight. The result showed that the feed with $31 \%$ protein content gave better performance and significant different $(P<0.05)$ than $27 \%$ protein feed. The feed content $31 \%$ protein was optimum for green catfish fingerlings and gave higher average individual weight gain $(80.48 \mathrm{~g})$, specific growth rate (2.67\%), fat retention (29.48\%) and better feed conversion ratio (2.28). Survival rates were the same for 2 treatments and ranged between $94.17 \%-95.18 \%$
\end{abstract}

KEYWORDS: Hemibagrus nemurus, grow out, feed, protein

\section{INTRODUCTION}

Catfishes of the family Pangasiidae have a great economics important fish in Indonesia. Hemibagrus nemurus, is one of the most appreciated fish species for the consumers in Sumatera and other Indonesia areas. This species originally lives in river and open water areas, but at present it almost becomes an extinct species due to over fishing. Its intensive culture has not been possible due to the lack of fry. In this context, the control of this reproduction in captivity represents a strategic goal. Several research about behaviour and wild resources of green catfish were conducted by Samuel et al. (1995) and breeding aspects by Hardjamulia \& Suhenda (2000); Sukendi (2001). The grow out culture was conducted by Muflikhah \& Aida (1996) using fry which were catched from wild.

The succeed in the artificial propagation and fry rearing including feed aspects offers new possibilities of seed availability for fish farmers. The success of mass production of $H$. nemurus fry was reached in fish hatchery, Gandus, Palembang in 2008 (Suhenda \& Samsudin, 2008). This breeding succeed was supported by using special quality of broodstock feed. According to Izquierdo et al. (2001); Woynarovich \& Horvath (1980); Elliot (1979); Wooton (1979); and Takeuchi \& Watanabe (1977), good quality broodstock feed with perfect rations influences egg quality and good quality offsprings.

\# Corresponding author. Research Institute for Freshwater Aquaculture, J. Sempur No. 1, Bogor 16154 , West Java, Indonesia. Tel.: + 62251313200

E-mail address: jap_oedino@yahoo.com 
Feed has an important role in the success of fish culture. There are three main factors an influencing on growth rate: protein level, feeding rate, and energy content in the diet. They are all related and influenced by each other. Therefore, optimal level of protein should be defined. Protein is the most important nutrient in fish feed from the stand point of growth performance and total feed cost. Although protein can readily utilized as energy, protein has to be utilized for protein purposes instead of converting into energy (NRC, 1983; Lovell, 1988). The purposes of protein are for body maintenance, building body structure, body protein, and growth (Cowey \& Sargent, 1972; Khan et al., 1973). Catfishes need feed with protein content of 30\%-32\% for their growth.

At presents, $H$. nemurus has a great potential to be cultured in floating net cage, earthern pond, bamboo cage (in the river) etc. The breeding and larval rearing of this species under control condition were successful. This species was fast adapted and good respond to artificial feed Hardjamulia \& Suhenda (2000). In the framework of development of fish farming in South Sumatra, rearing of fish in floating net cages need to be done. There were $27 \%$ and $31 \%$ of protein feed content which is available in the market. Evaluation of fish growth with available commercial fish in the floating net cage provides an overview of the performance of baung fish to the fish farmers. The study was conducted in floating net cage (belonged to the fish farmer) with the target consumption size (100-150 $\left.\mathrm{g} \mathrm{fish}^{-1}\right)$. The objective of this study was to define the protein content of the feed which influenced growth of $H$. nemurus fingerlings.

\section{MATERIALS AND METHODS}

\section{Experimental Fish and Culture Facilities}

Experimental fish were obtained from sexually mature brood stock cultured in earthern ponds. They were induced to spawn using hormone injection. The obtained fry were reared for two weeks in hapa. The fry were harvested and selected for homogenous population. Two thousand fingerlings averaging $3.92 \pm 0.32 \mathrm{~g}$ of individual body weight were stocked in each of floating net cage. The size of each floating net cage was ( $3 \mathrm{~m} \times 3 \mathrm{~m} \times 3 \mathrm{~m})$ and located in Musi River, Palembang. The experimental fish were acclimatized to experimental facilities for two weeks prior to the experiment. The period of the experiment was 4 months.

\section{Feed and Feeding}

Two commercial diets (sinking type) were used as experimental feed. The proximate analysis of experimental diet is given in Table 1 .

It showed that the protein content of the pelleted feeds were $27 \%$ and $31 \%$ with each diet contain $2840 \mathrm{kCal} / \mathrm{kg}$ feed and $2890 \mathrm{kcal} /$ $\mathrm{kg}$ feed, respectively (based on calculation) (Table 1). Each diet was fed to the fish with daily feeding rate of $4 \%-8 \%$ of the biomass. Fish were fed four times daily (at 8.00; 12.00; 16.00; and 20.00). Feeding allowances were adjusted every 1 month based on the new total weigh of fish in every cage after sampling.

\section{Data Analysis}

Completely randomized design was used in this experiment with 2 treatments (feed contain $27 \%$ and $31 \%$ protein). Each treatment has 3 replications.

Parameters were calculated using equation as follows:

Specific growth rate (Castell \& Tiews, 1980)

$$
a=\frac{\ln W_{f}-\ln W_{i}}{\text { Number of days }} \times 100 \%
$$

where:

$\mathrm{a}=$ Specific growth rate (\%)

$\mathrm{W}_{\mathrm{f}}=$ Final weight $(\mathrm{g})$

$\mathrm{W}_{\mathrm{i}}=$ Initial weight $(\mathrm{g})$

Table 1. Analysis proximate of experimental diets (dry basis)

\begin{tabular}{ccccccc}
\hline \multirow{2}{*}{ Diet s } & \multirow{2}{*}{$\begin{array}{c}\text { Moist ure } \\
\text { (\%) }\end{array}$} & \multicolumn{5}{c}{ Nut rient content (\%) } \\
\cline { 3 - 7 } & & Protein & Fat & Ash & Crude & NFE \\
\hline Diet A & 7.2 & 27.1 & 7.48 & 10.46 & 3.46 & 51.5 \\
Diet B & 5.6 & 31.54 & 6.65 & 8.84 & 2.98 & 49.99 \\
\hline
\end{tabular}

Note: NFE = Nitrogen free extract 
Protein efficiency ratio (Castell \& Tiews, 1980)

$$
\text { PER }=\frac{\text { Weight gain }(\mathrm{g})}{\text { Protein feed consumed }(\mathrm{g})}
$$

Protein retention (Viola \& Rappaport, 1979)

$$
\mathrm{PR}=\frac{\text { Protein weight gain }(\mathrm{g})}{\text { Protein feed consumed }(\mathrm{g})} \times 100 \%
$$

Fat retention (Viola \& Rappaport, 1979)

$$
\mathrm{FR}=\frac{\text { Fat weight gain }(\mathrm{g})}{\text { Fat feed consumed }(\mathrm{g})} \times 100 \%
$$

Feed conversion ratio (NRC, 1977)

$$
F C R=\frac{\text { Total weight of feed fed }(g)}{\left(W_{t}+D\right)-W_{o}} \times 100 \%
$$

where:

$\mathrm{FCR}=$ Feed Conversion Ratio

$\mathrm{W}_{\mathrm{t}}=$ Total final weight $(\mathrm{g})$

$\mathrm{W}_{\mathrm{o}}=$ Total initial weight $(\mathrm{g})$

$\mathrm{D}=$ Total weight of dead fish (g)

\section{RESULT AND DISCUSSION}

The result showed that there was significant different $(\mathrm{P}<0.05)$ between treatments for specific growth rate value. Specific growth rate value $(2.67 \%)$ for $31 \%$ protein was higher than that of $27 \%$ protein feed (Table 2 ).

Average individual weight $(84.38 \mathrm{~g})$ for $31 \%$ protein was higher than of $27 \%$ protein $(78.98$ g). The final weight of fish which was fed by $31 \%$ protein was 21.64 times or increase up to $2164 \%$. The average individual weight every sampling is presented on Figure 1. On the second sampling, the growth difference of the two protein conten were newly seen. On the first sampling, it has not clearly seen the difference between the treatment effect. At that time, it was still in a period of adaptation. Weight difference between the two feed in each sampling was $0.54 \mathrm{~g}, 1.36 \mathrm{~g}, 4.61 \mathrm{~g}$, and $8.42 \mathrm{~g}$ respectively.

There was significant different $(P<0.005)$ between treatments for feed conversion ratio (Table 3), while survival rate was not significant different $(P>0.05)$ between two treatments. The survival rate ranged between $94.17 \%$ - $95.18 \%$ (Table 3).

The values of protein efficiency ratio, protein retention, and fat retention were significant different $(P<0.05)$ between treatments (Table 4).

The result of experiment showed that the specific growth rate $(2.67 \%)$ of fish which were fed with $31 \%$ protein feed was higher than that $27 \%$ protein (Table 2 ). This value also higher than Hemibagrus nemurus specific growth rate (1.29\%) which was fed by (29\%-30\%) protein feed (Hardjamulia \& Suhenda, 2000). Millamena et al. (2002) stated that protein is the most important nutrient. Protein is important for tissue building, hormone, and enzyme which are used for growth processes. The result of Pongmaneerat et al. (1993) studied on common carp showed that $32 \%$ protein feed gave better growth compare to feed containing low protein.

The high level protein content increases an individual body weight (Figure 1). This is indicated that $31 \%$ protein feed gave better fish body growth. Hemibagrus nemurus fed with $31 \%$ protein feed reached better feed conversion ratio $(2.28)$ than that of $27 \%$. The value of feed conversion ratio is an indicator of feed effectivity. The value (2.28) of this feed conversion ratio is also better than that of 3.30 ,

Table 2. Specific growth rate (\%), average individual weight (g) and final weight (g) of green catfish during 4 months rearing period.

\begin{tabular}{cccc}
\hline $\begin{array}{c}\text { Treatment /Feed } \\
\text { protein content } \\
(\%)\end{array}$ & $\begin{array}{c}\text { Specific } \\
\text { growth rate } \\
\mathbf{( \% )}\end{array}$ & $\begin{array}{c}\text { Average individual } \\
\text { weight gain } \\
\mathbf{( g )}\end{array}$ & $\begin{array}{c}\text { Final weight } \\
\mathbf{( g )}\end{array}$ \\
\hline 27 & $2.57^{\mathrm{a}} \pm 0.05$ & $72.01^{\mathrm{a}} \pm 4.36$ & $78.98\left(2005 \%^{*}\right)$ \\
31 & $2.67^{\mathrm{b}} \pm 0.04$ & $80.48^{\mathrm{b}} \pm 2.09$ & $84.38(2164 \%)$ \\
\hline
\end{tabular}

Note: Number followed by the same letter is not significantly different Note: *=Final weight/initial body weight (x $100 \%)$ 


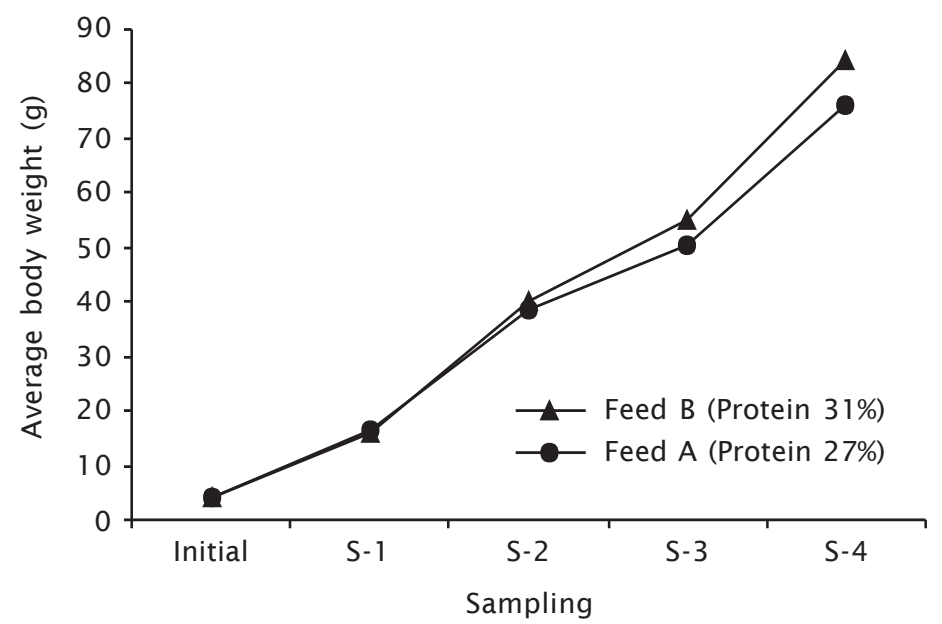

Figure 1. Average body weight ( $\mathrm{g} / \mathrm{fish}$ ) each sampling time

Table 3. Feed conversion ratio and survival rate (\%) for each treatment

\begin{tabular}{ccc}
\hline $\begin{array}{c}\text { Treatment/Feed protein } \\
\text { content (\%) }\end{array}$ & $\begin{array}{c}\text { Feed conversion } \\
\text { ratio }\end{array}$ & Survival rate \\
\hline 27 & $2.46^{\mathrm{a}} \pm 0.15$ & $94.17^{\mathrm{a}} \pm 4.26$ \\
31 & $2.28^{\mathrm{b}} \pm 0.07$ & $95.18^{\mathrm{a}} \pm 1.06$ \\
\hline
\end{tabular}

Note: Number followed by the same letter is not significantly different

Table 4. Protein efficiency ratio, protein retention (\%), and fat retention (\%) of Hemibagrus nemurus during 4 months rearing period

\begin{tabular}{cccc}
\hline $\begin{array}{c}\text { Treatment/Feed protein } \\
\text { content (\%) }\end{array}$ & $\begin{array}{c}\text { Protein efficiency } \\
\text { ratio }\end{array}$ & $\begin{array}{c}\text { Protein } \\
\text { retention }\end{array}$ & Fat retention \\
\hline 27 & $1.63^{\mathrm{a}} \pm 0.10$ & $23.17^{\mathrm{a}} \pm 4.36$ & $22.17^{\mathrm{a}} \pm 1.14$ \\
31 & $1.48^{\mathrm{b}} \pm 0.05$ & $20.74^{\mathrm{b}} \pm 2.09$ & $29.48^{\mathrm{b}} \pm 0.73$ \\
\hline
\end{tabular}

Note: Number followed by the same letter is not significantly different

conducted by Hardjamulia \& Suhenda (2000) study. Survival rates of Hemibagrus nemurus which were cultured in floating net cages, in Musi river varied from $94.17 \%-95.18 \%$.

Fish culture in floating net cage gave better result compare to the earthern pond with lower water circulation (Zonneveld \& Huisman, 1990). Fish culture in floating net cage with optimal feed and feeding will give better feed conversion ratio and survival rate.

Protein retention is an indication the effort of fish in using and storing protein in body tissue. The value of protein retention for $27 \%$ protein feed $(23.17 \%)$ was higher than that of $31 \%$ protein $(20.74 \%)$. The difference of this result was probably caused the protein quality which was used in the feed. Protein retention value is depend on protein quality, amino acid composition and energy protein ratio of the feed (Pongmaneerat et al., 1993).

Deposition of fat in the body or fat retention is related to the energy and carbohydrate content of the feed. Fat retention for $31 \%$ protein feed was higher (29.48\%) than that of $27 \%$ protein feed. 


\section{CONCLUSION}

Base on observed data, 31\% protein feed gave better growth performances for Hemibagrus nemurus which were cultured in floating net cage.

\section{REFERENCES}

Castel, J.D. \& Tiews, K. 1980. Report of the EIFAC, IUNS and ICES Working Group on the standarization of metodology in fish nutrition research. Hamburg. Germany, EIFAC Tech. Paper, $24 \mathrm{pp}$.

Cowey, C.B. \& Sargent, J.R. 1972. Fish Nutrition. Advances in Marine Biology, 10: 303-477.

Elliot, J.M. 1979. Energetic of freshwater teleost, In: P.J. Miller (Ed). Fish phenology adaptive. Acad. Press. Inc. London, p. 9-61.

Hardjamulia, A. \& Suhenda, N. 2000. Evaluasi sifat reproduksi dan sifat gelondongan generasi pertama empat strain ikan baung (Mystus nemurus) di karamba jaring apung. J. Pen. Perik. Indonesia, 6(3-4): 24-35.

Izquierdo, M.S., Fernandez, H., Palacios, \& Tacom, A.G.J. 2001. Effect of broodstock nutrition on reproductive performance of fish. Aquaculture, 197: 25-42.

Khan, M.S., Ang, M.A.K.J., \& Sat, C.R. 1973. Optimum Protein Requirement of a Malaysian Freshwater Catfish (Mystus nemurus). Aquaculture, 112: 227-235.

Lovell, T. 1988. Nutrition and Feeding of Fish. Van Nostrand Reinhold, New York, 260 pp.

Millamena, O.M., Colloso, R.M., \& Pascual, F.P. 2002. Nutrition in tropical aquaculture: essentials of fish nutrition, feeds, and feeding of tropical aquatic species, $280 \mathrm{pp}$.

Muflikhah, N. \& Aida, S.N. 1996. Pengaruh frekuensi pemberian pakan yang berbeda terhadap pertumbuhan dan kelangsungan hidup benih ikan baung (Mystus nemurus). Prosiding Lolitkanwar, 2: 108-111.

National Research Council (NRC). 1977. Nutrient Requirement of Warmwater Fishes and
Shellfishes. National Academy of Sciences. Washington D.C., 78 pp.

National Research Council (NRC). 1983. Nutrient Requirement of Warmwater Fishes and Shellfishes. National Academy of Sciences. Washington D.C., 102 pp.

Pongmaneerat, J., Watanabe, T., \& Takeuchi, T. 1993. Use of different protein meals as partial or total substitution for fish meal in carp diets. Nippon Suisan Gakkaishi, (59): 1,249-1,257.

Samuel, Adjie, S., \& Akriani. 1995. Beberapa aspek biologi ikan baung (Mystus nemurus) di daerah aliran Sungai Batanghari, Provinsi Jambi. Oseanologi dan Limnologi di Indonesia, 28: 1-13.

Suhenda, N. \& Samsudin, R. 2008. Produksi benih ikan baung di UPR dalam mendukung IPTEKMAS. Laporan Hasil Riset. Balai Riset Perikanan Budidaya Air Tawar, 10 pp.

Sukendi. 2001. Biologi reproduksi dan pengendaliannya dalam upaya pembenihan ikan baung (Mystus nemurus) di perairan Sungai Kampar, Riau. Disertasi. Program Pasca Sarjana, IPB, 217 pp.

Takeuci, T. \& Watanabe, T. 1977. Requirement of carp for essensial fatty acids. Bull. Japan Soc. Sci. Fish., 43(5): 541-551.

Viola, S. \& Rappaport, U. 1979. The "Extra Calorie Effect" of Oil in Nutrition of Carp. Bamidgeh, 31(3): 51-69.

Wooton, R.J. 1979. Energy cost production and environmental determinant of fecundity in teleost fishes. In Miller, P.J. (Ed.). Fish pheonology, anabolic adaptive in teleost. Acad. Press. Inc London, p. 133-159.

Woynarovich, E. \& Horvath, L. 1980. The artificial propagation of warm water fish. A manual for extention FAO, Fishes Technical Paper, 201: 285.

Zonneveld \& Huismann, A. 1990. Dasar-dasar Budidaya. Pustaka Gramedia. Jakarta, 318 pp. 